\title{
PROFIL USAHA PEMBUATAN TEMPE CV CIPTA PANCA PERSADA KLEAK KECAMATAN MALALAYANG KOTA MANADO
}

\author{
Silva Tangkabiringan \\ Benny Adrian Berthy Sagay \\ Melsje Yellie Memah
}

\begin{tabular}{ll}
\hline Naskah diterima melalui Website Jurnal Ilmiah agrisosioekonomi@ @unsrat.ac.id & : Jumat, 12 Juli 2019 \\
Disetujui diterbitkan & : Kamis, 25 Juli 2019 \\
\hline
\end{tabular}

\begin{abstract}
This study aims to examine the profile of tempe making business at CV Cipta Panca Persada. The business profile is limited to obtaine of the amount of profits. This research was conducted for 3 months starting from May to July 2018. The data used in this study are primary data and secondary data. Primary data is obtained from direct interviews with business owners (one respodent) using a list of questions that have been provided. While secondary data is obtained from the Agriculture Faculty library, the internet by using a google search engine to access articles from various scientific journals and theses from other universities related to this research topic concerning business profile. The results showed that the amount of tempe produced in one day was 50 packs of small packs at a price of Rp. 3,500 per package and 200 medium packages at Rp. 6,500 per package. The production process is one month (31 days) in July 2018, obtaining a total revenue of Rp. 39,000,000 with a total cost of Rp. 16,775,714, resulting in a profit of $R p .22,224,286 .{ }^{*}{ }^{*}$ prm ${ }^{*}$
\end{abstract}

Keywords: business profile, tempe, profit

\begin{abstract}
ABSTRAK
Penelitian ini bertujuan untuk mengkaji profil usaha pembuatan tempe pada CV Cipta Panca Persada. Adapun profil usaha tersebut dibatasi pada besarnya keuntungan yang diperoleh. Penelitian ini dilaksanakan selama 3 bulan mulai dari bulan Mei sampai Juli 2018. Data yang digunakan dalam penelitian ini adalah data primer dan data sekunder. Data primer diperoleh dari wawancara langsung dengan pemilik usaha menggunakan daftar pertanyaan yang telah disediakan. Sedangkan data sekunder diperoleh dari internet dengan menggunakan mesin pencarian google untuk mengakses artikel dari berbagai jurnal ilmiah dan skripsi dari perguruan tinggi lain yang berkaitan dengan penelitian ini topik menyangkut profil usaha. Hasil penelitian menunjukkan bahwa banyaknya produksi tempe yang dihasilkan dalam satu hari sebanyak 50 bungkus kemasan kecil dengan harga Rp. 3.500 per kemasan dan 200 kemasan sedang dengan harga Rp. 6.500 per kemasan. Proses produksi selama satu bulan (31 hari) pada bulan Juli 2018, memperoleh total penerimaan sebesar Rp. 39.000.000 dengan total biaya sebesar Rp. 16.775.714, sehingga menghasilkan keuntungan sebesar Rp. 22.224.286. ${ }^{{ }^{e p r m} *}$
\end{abstract}

Kata kunci: profil usaha, tempe, keuntungan 


\section{PENDAHULUAN}

\section{Latar Belakang}

Indonesia merupakan negara yang dikenal dengan beragam jenis makanan khas, satu diantara makanan khas asal Indonesia yang cukup mendunia adalah tempe. Tempe merupakan makanan sumber protein tinggi, tempe mempunyai harga relatif lebih murah apabila dibandingkan dengan sumber protein asal hewani seperti daging, susu dan telur. Proses pembuatan tempe sederhana dan mudah, kandungan gizinya pun cukup tinggi.(Cahyadi, 2006).

Tabel 1. Kandungan zat-zat makanan dalam kedelai

\begin{tabular}{lcc}
\hline Unsur-Unsur Zat Makanan & Kedelai Putih & Kedelai Hitam \\
\hline Air & 13,75 & 14,05 \\
Protein & 41,00 & 40,40 \\
Lemak & 15,80 & 19,30 \\
Karbonhidrat & 14,82 & 14,10 \\
Mineral & 5,25 & 5,25 \\
\hline Sumber :AAK, 1990 & &
\end{tabular}

CV Cipta Panca Persada merupakan salah satu diantara UKM yang memproduksi Tempe. CV Cipta Panca Persada berlokasi dikelurahan Kleak Kecamatan Malalayang, Usaha ini berdiri sejak tahun 1989, sudah berdiri selama 30 tahun. Pada mulanya usaha ini merupakan usaha yang tergolong cukup kecil tapi seiring berjalanya waktu usaha ini telah berkembang menjadi CV Cipta Panca Persada. Usaha ini milik sendiri sehingga dapat dikategorikan usaha industri kecil. Pengelola (pemilik) usaha adalah ibu sunarmi umur 68 tahun, pendidikan terakhir SMP, pemilik terlibat langsung dalam proses produksi dan menjadi penanggung jawab terhadap semua keputusan dalam setiap kegiatan produksi. CV Cipta Panca Persada merupakan salah satu usaha yang menggunakan kedelai sebagai bahan baku utama dalam pembuatan tempe. Kedelai yang digunakan adalah kedelai impor dari luar negeri melalui distributor.

Berdasarkan penjelasan di atas peneliti tertarik untuk mengetahui "Profil Usaha Pembuatan Tempe CV Cipta Panca Persada di Kelurahan Kleak Kecamatan Malalayang Kota Manado".

\section{Tempe}

Tempe adalah makanan yang dibuat dari kacang kedelai yang difermentasikan menggunakan kapang Rhizopus oligosporus, kegiatan fermentasi melibatkan tiga faktor pendukung yaitu, bahan baku yang diolah (kedelai), mikroorganisme (jamur tempe) dan lingkungan tumbuh. Proses pembuatan tempe yang terdiri atas perendaman, pencucian, pembilasan dan fermentasi secara akumultatif telah mampu menghancurkan zat gizi yang terdapat pada kedelai mentah. Teknologi tradisional dan relatif sederhana ini telah mampu menghancurkan zat anti gizi pada kedelai sekaligus menghasilkan zat gizi utama yang mampu memperbaiki mutu gizi kedelai (Winarno, 1993) dalam Kusaeri Aulani (2014).

\section{Konsep Profil Perusahaan}

\section{a. Pengertian Profil Perusahaan}

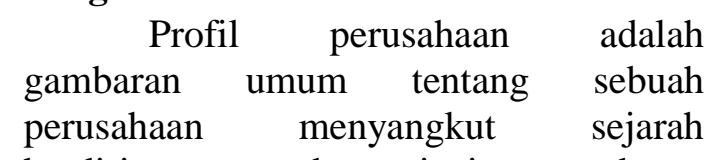
berdirinya perusahaan, jenis perusahaan, struktur organisasi perusahaan, sistem permodalan, dan alamat perusahaan. Profil perusahaan ini berguna untuk beberapa hal pengajuan peminjaman modal ke bank, untuk diperkenalkan ke publik, dan sebagainya (Profil Perusahaan-Contoh dan Pengertian, 2012).

\section{b. Jenis Bidang Usaha}

1. Usaha Ekstraktif

Merupakan usaha yang bergerak dalam bidang pertambangan atau bidang usaha yang mengambil langsung dari alam, seperti hasil laut dan hutan.

\section{Usaha Argaris}

Mencakup berbagai usaha pengelolaan kebun, perdagangan hasil pertanian (agrobisnis) dan perternakan.

3. Industri 
Merupakan bentuk usaha yang menghasilkan suatu komoditas barang.

4. Perdagangan

Meliputi usaha dagang berbagai komoditi baik skala besar maupun kecil (perdagangan besar dan enceran).

5. Jasa

Merupakan usaha menghasilkan jasa (non barang).

\section{Industri Rumah Tangga}

Berdasarkan jumlah tenaga kerja, industri terbagi menjadi beberapa kategori yaitu :

a. Industri rumah tangga dengan pekerja kurang dari 5 orang.

b. Industri kecil dengan pekerja 5-19 orang.

c. Industri sedang dengan pekerja 20-99 orang.

d. industry besar dengan pekerjaan 100 orang atau lebih.

\section{Faktor- faktor yang Mendukung}

Pengembangan Usaha Pembuatan Tempe "CV Cipta Panca Persada"

\section{a. Modal}

Modal mutlak diperlukan dalam usaha. Tanpa modal sudah pasti usaha tidak bisa dilakukan. Modal atau kapital mengandung banyak arti, tergantung pada penggunaannya. Dalam arti sehari-hari, modal sama artinya dengan harta kekayaan seseorang. Yaitu semua harta berupa uang, tabungan, tanah, rumah, mobil, dan lain sebagainya yang dimiliki. modal atau kapital adalah segala jenis barang yang dihasilkan dan dimiliki masyarakat, disebut dengan kekayaan masyarakat (Daniel Moehar, 2002).

b. Bahan Baku

Bahan baku merupakan salah satu faktor input yang sangat diperlukan, karena tanpa adanya bahan baku, proses produksi tidak dapat berjalan. Industri pengolahan hasil pertanian adalah industri yang bahan bakunya berasal dari hasil- hasil pertanian yang sangat membutuhkan bahan baku dalam jumlah yang banyak, kualitas, dan waktu yang tetap terus-menerus (Assuari, 1999 dalam skripsi Kurniawan, 2005).

\section{c. Tenaga Kerja}

Tenaga kerja adalah satu faktor yang penting dalam membangun sebuah usaha. Setiap proses produksi diperlukan tenaga kerja yang cukup memadai. Jumlah tenaga kerja yang diperlukan perlu disesuaikan dengan kebutuhan sampai tingkat tertentu sehingga jumlahnya optimal (Soekartawi, 2001).

\section{d. Pengelolaan (Manajemen)}

Manajemen merupakan sebuah subjek yang mempersoalkan usaha penetapan dan pencapaian tujuan. Sebagai alat manajemen bukan saja ditujukkan untuk mengidentifikasi, menganalisa, dan menetapkan tujuantujuan yang harus dicapai, tetapi juga untuk mengkombinasikan secara efektif bakat dan keahlian orang-orang dan mendayagunakan sumber-sumber material secara efisien (Ariadi Yudi Bambang dkk, 2011)

\section{Pemasaran dan Saluran Pemasaran}

\section{a. Pemasaran}

Pemasaran adalah salah satu faktor produksi yang penting sebagai persyaratan berkembangnya industri pada satu wilayah atau lokasi. Berdasarkan uraian tersebut dijelaskan bahwa pasar dalam hal ini orientasi pasar sangat penting dan menentukan terhadap usaha tempe bahkan dapat dipahami bahwa keberhasilan suatu usaha tergantung pada komponen pasar. Dengan tingginya permintaan pasar secara langsung akan terbuka bagi pengusaha tempe dapat mengembangkan usahanya dalam proses jangka panjang (Ryanto, 2010).

\section{b. Saluran Pemasaran}

Saluran pemasaran menurut fandy Tjiptono (2008) adalah kegiatan pemasaran yang berusaha memperlancar dan mempermuda penyampaian barang dan jasa dari produsen kepada konsumen, sehingga penggunaannya sesuai dengan yang diperlukan (jenis, jumlah, harga, tempat, dan saat dibutuhkan). 


\section{Konsep Biaya Produksi , Harga, Penerimaan, dan Keuntungan}

\section{a. Konsep Biaya}

Menurut Mulyadi (2009) Biaya dapat dibagi berdasarkan sifatnya, artinya mengkaitkan antara pengeluaran yang harus di bayar dengan produk atau output yang dihasilkan yaitu :

a) Biaya Tetap (Fixed Cost) adalah biaya yang besarnya tidak tergantung pada jumlah produksi.

b) Biaya Variabel (Variabel Cost) adalah biaya yang besarnya, tergantung pada tingkat produksi.

c) Biaya Total (Total Cost) merupakan penjumlahan dari biaya tetap dan biaya variabel dalam proses produksi.

\section{b. Konsep Harga}

Harga adalah variabel yang dapat dikendalikan dan dapat menentukan diterima tidaknya suatu produk oleh konsumen. Murah atau mahalnya harga suatu produk sangat relatif sifatnya (Anoraga, 2002). Harga yaitu sejumlah kompensasi baik yang berupa uang maupun barang yang dibutuhkan.

Harga yang tepat adalah harga yang sesuai dengan kualitas produk suatu barang, dan harga tersebut dapat memberikan kepuasan kepada konsumen (Supriyono, 2000).

\section{c. Konsep Penerimaan (Revenue)}

Penerimaan adalah jumlah nilai atau hasil penjualan yang diterima dalam menjalankan usaha. Total penerimaan dalam usaha diperoleh dari produksi fisik dikalikan dengan harga produksi (Soekartawi, 2006). Penerimaan yaitu hasil perkalian antara jumlah produksi Tempe dengan harga jual (Rp/bungkus).

$$
\mathbf{T R}=\mathbf{Q} \times \mathbf{P}
$$

Keterangan :

$$
\begin{array}{ll}
\mathrm{TR} & =\text { Penerimaan total }(\mathrm{Rp}) \\
\mathrm{Q} & =\text { Jumlah produksi } \\
\mathrm{P} & =\text { Harga dari hasil produksi }(\mathrm{Rp})
\end{array}
$$

\section{Keuntungan}

Keuntungan adalah selisih antara penerimaan dengan semua biaya. Keuntungan maksimum dapat ditingkatkan dengan cara meminimumkan biaya untuk penerimaan yang tepat atau meningkatkan penerimaan dengan biaya (Soekartawi, 1995), yaitu :

Dimana :

$$
\boldsymbol{\pi}=\mathbf{T R}-\mathbf{T C}
$$

$$
\begin{array}{ll}
\pi & =\text { Keuntungan } \\
\mathrm{TR} & =\text { Total Penerimaan (Total Revenue) } \\
\mathrm{TC} & =\text { Total Biaya (Total Cost) }
\end{array}
$$

\section{Rumusan Masalah}

Berdasarkan latar belakang yang telah diuraikan di atas maka masalah dalam penelitian ini adalaa sebagai berikut:

1. Bagaimana profil usaha Pembuatan Tempe CV Cipta Panca Persada di Kleak Kecamatan Malalayang?

2. Bagaimana pendapatan usaha Pembuatan Tempe CV Cipta Panca di Kleak Kecamatan Malalayang?

3. Bagaimana saluran pemasaran usaha Pembuatan Tempe CV Cipta Panca Persada di Kleak Kecamatan Malalayang?

\section{Tujuan Penelitian}

Penelitian ini bertujuan untuk mengkaji profil Usaha Pembuatan Tempe CV Cipta Panca Persada di Kleak Kecamatan Malalayang serta keuntungannya.

\section{Manfaat Penelitian}

Manfaat yang ingin diperoleh dari penelitian ini, diantaranya adalah sebagai berikut :

1. Bagi peneliti, penelitian ini merupakan salah satu syarat untuk memperoleh gelar sarjana di Fakultas Pertanian Universitas Sam Ratulangi sekaligus menambah wawasan dan pengetahuan.

2. Bagi CV Cipta Panca Persada hasil penelitian ini diharapkan dapat digunakan sebagai bahan pertimbangan dalam meningkatkan keuntungan.

3. Bagi pembaca, hasil penelitian ini diharapkan dapat dijadikan sebagai bahan referensi dan pertimbangan dalam melakukan penelitian lanjutan. 


\section{METODOLOGI PENELITIAN}

\section{Lokasi dan Waktu Penelitian}

Penelitian ini dilakukan selama 3 bulan, mulai dari tahap persiapan hingga penyusunan laporan yakni mulai bulan Mei Tahun 2018 sampai bulan Juli Tahun 2018. Penelitian dilaksanakan di CV Cipta Panca Persada yang berlokasi di Kelurahan kleak Kota Manado Sulawesi Utara.

\section{Metode dan Teknik Pengumpulan Data}

Data yang digunakan dalam penelitian ini adalah data primer dan data sekunder. Data primer yang diperoleh melalui wawancara langsung dengan pemilik usaha CV Cipta Panca Persada. Sedangkan data sekunder diperoleh dari perusahaan tersebut terkait dalam penelitian ini seperti sejarah dan struktur perusahaan.

Teknik pengumpulan data dilakukan sebagai berikut :
a. Observasi
b. Wawancara

\section{Kosep Pengukuran Variabel yang dihitung dalam Profil Usaha Pembuatan Tempe CV Cipta Panca Persada.}

Hal-hal yang akan diteliti pada profil usaha pembuatan tempe "CV Cipta Panca Persada" :

a. Modal

Modal adalah peralatan dan uang yang dipakai dalam usaha produk tempe. Dinyatakan dalam satuan rupiah (Rp).

b. Bahan Baku

Bahan baku utama dalam pembuatan produk tempe adalah kedelai. Kedelai merupakan bahan dasar yang digunakan sehingga tercipta produk tempe. Penggunaan kedelai $50 \mathrm{~kg} /$ produksi dengan harga per kilo Rp 8.500.

c. Bahan Penolong

1) Ragi Tempe, digunakan sebagai bahan campuran dalam proses fermentasi. Banyaknya ragi tempe yang di perlukan dalam satu bulan proses produksi 2 bungkus sebanyak $500 \mathrm{gr} /$ bungkus.

2) Daun pisang dan kemasan pelastik, digunakan untuk pengemasan produk tempe. Dibutuhkan 10 lembar daun pisang dalam satu kali produksi dengan harga Rp. 10.000. sedangkan kemasan pelastik 1 pak dengan harga yang sama.

d. Tenaga kerja

Tenaga kerja yang digunakan dari dalam keluarga terdiri dari dua orang sedangkan tenaga kerja dari luar keluarga hanya satu orang.

e. Biaya produksi

Biaya produksi adalah besarnya biaya yang dikelurkan pada usaha tempe $\mathrm{CV}$ Cipta Panca Persada (Rp/bulan) yang terdiri atas :

1. Biaya tetap meliputi :

Biaya penyusutan peralatan, (mesin penggiling, pompa air, bak besar, dandang, mesin penjepit dan kompor gas).

2. Biaya variabel meliputi :

- Biaya bahan baku (kedelai)

- Biaya bahan penolong (ragi tempe, daun pisang, kemasan pelastik)

- Biaya tenaga kerja

- Biaya transportasi

3. Saluran Pemasaran

Saluran pemasaran dalam penelitian ini produk dari produsen diantarkan langsung kepada konsumen yaitu dari pihak usaha langsung mengantarkan produk kepada supermarket yang telah berkerja sama seperti golden, jumbo, happermart, indogrosir, multimart, freshmart, gyan.

4. Keuntungan

Keuntungan yaitu selisi antara total penerimaan dan total biaya yang dikeluarkan (Rp/bulan).

a) Untuk mengetahui profil usaha pembuatan tempe CV Cipta Panca Persada dianalisis dengan menggunakan 
metode deskriptif yaitu data yang dikumpulkan kemudian diolah dan disajikan dalam bentuk tabel.

b) Proses perhitungan yang digunakan untuk mendapatkan biaya-biaya yang diperoleh akan digunakan beberapa bentuk rumus diantaranya :

Untuk mendapatkan biaya penyusutan maka rumus yang digunakan adalah :

Dimana :

$$
\mathbf{D}=\frac{\mathbf{P}-\mathbf{S}}{\mathbf{n}}
$$

D $($ Depreciation $)=$ Biaya Penyustan (Rp/thn)

$\mathrm{P}($ Price $) \quad=$ Harga Awal Barang

(Rp)

S (Salvage Value $)=$ Harga Akhir Barang

(Rp)

$\mathrm{N}$ (Life Time) $=$ Perkiraan Umur Ekonomis (Tahun)

Untuk mengetahui berapa besar biaya produksi yang digunakan dalam proses produksi tempe menggunakan rumus :

Dimana :

$$
\mathbf{T C}=\mathbf{F C}+\mathbf{V C}
$$

$\begin{array}{ll}\text { TC }(\text { Total Revenue }) & =\text { Total Biaya } \\ \text { FC }(\text { Fixed Cost }) & =\text { Biaya Tetap } \\ \text { VC }(\text { Variabel Cost }) & =\text { Biaya Variabel }\end{array}$

Untuk mengetahui besar tingkat penerimaan yang diperoleh dapat menggunakan rumus:

$$
\begin{array}{ll}
\text { TR } & =\text { Total Penerimaan } \\
\mathrm{Q} & =\text { Jumlah Produksi yang dijual } \\
\mathrm{P} & =\text { Harga dari hasil produksi }
\end{array}
$$$$
\text { Dimana : }
$$

Untuk mengukur benar keuntungan digunakan rumus sebagai berikut :

$\begin{array}{lll} & \boldsymbol{\pi}=\mathbf{T R}-\mathbf{T C} \\ \text { Dimana } & \\ \pi & =\text { Profit (Keuntungan) } \\ \mathrm{TR} & =\text { Total Revenue (Total } \\ & \text { Penerimaan) } \\ \mathrm{TC} & =\text { Total Cost (Total Biaya) }\end{array}$

\section{HASIL DAN PEMBAHASAN}

\section{Profil Usaha Pembuatan Tempe CV Cipta Panca Persada}

Deskripsi Umum Usaha Pembuatan Tempe CV Cipta Panca Persada

CV Panca Persada masih tergolong sebagai industri rumah tangga. Industri rumah tangga ini mengelolah kedelai menjadi tempe dengan jumlah tenaga kerja 1 orang. Lokasi industri ini berada di Kelurahan Kleak Kota Manado. Sebelah Utara berbatasan dengan Kecamatan Sario, Sebelah Timur berbatasan dengan Kecamatan Pineleng, Sebelah Selatan berbatasan dengan Kecamatan Pineleng, Sebelah Barat berbatasan dengan Laut Manado. Jumlah produksi yang dihasilkan terbilang masi sedikit dengan tenaga kerja yang sedikit, serta penguasaan teknologi yang masi sederhana.

Usaha industri ini merupakan usaha yang sudah berdiri cukup lama, telah beroperasi sejak tahun 1988 sampai dengan saat ini. Pemilik industri rumah tangga ini yaitu ibu Sunarmi, berumur 68 tahun. Alasan diberi nama tempe "Sucipto" adalah karena pada saat melakukan kerja sama dengan supermarket ibu Sunarmi harus menamai produk yang akan dijual, dan tanpa berpikir panjang ibu sunarmi memberikan nama produk jualanya itu "Sucipto" dimana sucipto itu adalah nama suami ibu Sunarmi.

Proses pembuatan tempe dilakukan setiap hari, dalam satu kali produksi membutuhkan $50 \mathrm{~kg}$ kedelai dan menghasilkan 250 bungkus produk tempe "Sucipto" berukuran sedang dan 50 bungkus ukuran kecil, dengan harga ukuran kecil $\mathrm{Rp}, 3.500$ sedangkan kemasan ukuran sedang seharga Rp. 6000.

Target pasar dari industri ini adalah supermarket-supermarket yang ada dikota manado seperti, Golden, Multimart, Jumbo, Hypermart, Freshmart, Fiesta Ria, Transmart Carrefour, Indogrosir dan Giant.

\section{Struktur Organisasi}

Berdasarkan hasil penelitian struktur organisasi CV Cipta Panca Persada sangatlah sederhana. Berikut ini adalah struktur organisasi CV Cipta Panca Persada pada Gambar 1. 


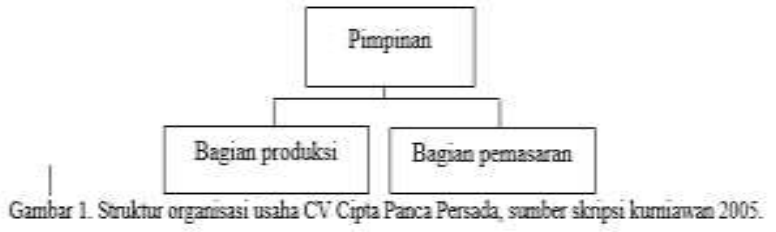

\section{Proses Produksi}

Berikut ini alat dan bahan serta proses pembuatan tempe langsung :

a. Bahan baku berupa kacang kedelai dan ragi tempe serta alat-alat yang digunakan yaitu mesin penggiling, pompa air, bak besar, dandang kemasan plastik, daun pisang.

b. Proses pembuatan produk tempe ( lihat dalam Gambar 2 ).

Berikut ini adalah alur proses produksi tempe kedelai "Sucipto":

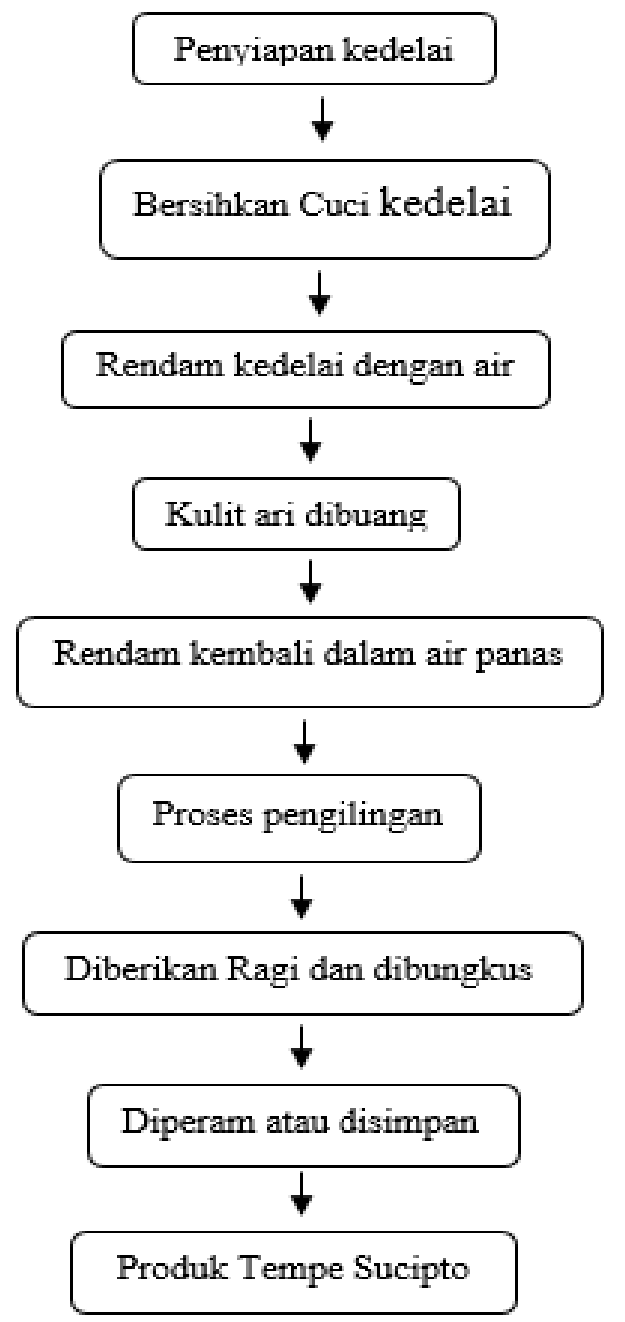

Gambar 2. Proses Pembuatan Tempe

\section{a. Bahan Baku}

\section{Pengunaan Bahan Baku}

Hasi penelitian menunjukan bahwa bahan baku yang digunakan dalam pembuatan produk tempe yaitu kedelai. Produk yang dihasilkan dari suatu industri akan tercipta karena adanya ketersediaan dan penggunaan bahan baku (skripsi kurniawan 2005). Perolehan bahan baku kedelai pada industri ini diperoleh dari distributor. Pihak industri membeli bahan baku kedelai dengan cara pemesanan langsung pada distributor, kemudian pihak distributor akan mengantarkan langsung ke industri. pemesanan dilakukan setiap sepuluh hari dengan jumlah bahan baku kedelai sebanyak $500 \mathrm{~kg}$ dengan harga perkilonya Rp.8.200. Penggunaan bahan baku kedelai dalam satu kali produksinya $50 \mathrm{~kg}$ kedelai yang diperlukan, dalam satu bulan produksinya diperlukan $1500 \mathrm{~kg}$ kedelai, biaya yang digunakan untuk bahan baku selama bulan september Rp.12.300.000, untuk Proses produksi ini dilakukan setiap hari, waktu pembuatan produk tempe untuk setiap kali produksinya memerlukan waktu 44-48 jam/proses atau kurang lebih dua hari, produk yang dihasilkan dalam satu kali produksi 250 bungkus, terdiri dari 50 bungkus produk tempe ukuran kecil dan 200 bungkus produk tempe ukuran sedang.

\section{b. Peralatan}

Dalam proses produksi pada usaha pembuatan tempe CV Cipta Panca Persada tentunya memerlukan peralatan tertentu berikut ini adalah peralatan yang diigunakan dalam proses produksi tempe sucipto dapat dilihat pada Tabel 2 .

Tabel 2. Peralatan Dalam Proses Produksi Usaha Pembuatan Tempe CV Cipta Panca Persada.

\begin{tabular}{clr}
\hline No & Jenis Alat & Jumlah (Rp) \\
\hline 1 & Mesin Penggiling & 3.000 .000 \\
2 & Pompa Air & 400.000 \\
3 & Bak Besar & 37.000 \\
4 & Dandang & 100.000 \\
5 & Kompor Gas & 500.000 \\
6 & Mesin Penjepit & 120.000 \\
7 & Gas & 30.000 \\
8 & Daun Pisang & 10.000 \\
9 & Kemasan Pelastik & 10.000 \\
\hline & Total
\end{tabular}

Sumber : Diolah Dari Data Primer 2018 


\section{c. Tenaga Kerja}

Pengunaan tenaga kerja dalam industri ini hanya mempekerjakan satu orang tenaga kerja, karena kebanyakan tenaga kerja yang digunakan dari dalam rumah tangga. Pengantaran produk tempe dilakukan oleh pemilik industri dibantu tenaga kerja untuk mengantarkan produk pesana ke supermarket yang memesan produk tempe. Pengantaran produk membutuhkan biaya bahan bakar Rp.300.000 per minggu dan untuk tenaga kerja mendapatkan upah Rp.1.900.000 per bulan.

\section{d. Pemasaran}

Pemasaran adalah suatu proses manajerial yang membuata individu atau kelompok mendapatkan apa yang mereka butuhkan dan inginkan dengan menciptakan, menawarkan dan mempertukarkan produk yang bernilai kepada pihak lain atau segalah kegiatan yang menyangkut penyampaian produk atau jasa mulai dari produsen sampai konsumen (Raja Oskar dkk 2010). Saluran pemasaran dari usaha industri tempe dappat dilihat pada gambar 3 dibawah ini :

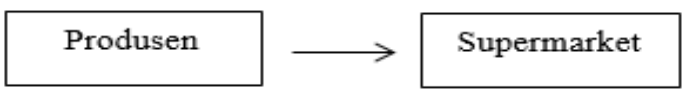

Gambar 3. Saluran pemasaran usaha tempe CV Cipta Persada

Saluran pemasaran pada usaha tempe sucipto merupakan saluran pemasaran tidak langsung yaitu dari produsen dijualkesupermarket dengan harga Rp.6000/bungkus, kemudian dari supermarket menjual ke konsumen dengan harga Rp.7.500. Jumlah produk yang dijual dari tempat produksi sebanyak 250 bungkus.

\section{Target Pasar}

Target pasar merupakan aspek yang sangat penting dalam menjalankan suatu usaha, sebuah usaha terlebih dahulu harus melakukan segmentasi pasar dengan cara mengelompokan konsumen atau pembeli. Setiap kelompok konsumen dapat dipilih sebaga target pasar yang akan dicapai. Dalam hal ini industri tempe Sucipto menetapkan sasaran pasar ke supermarket-supermarket seperti freshmart, golden, hypermart, jumbo, multimart dan indogrosir.
Adapun cakupan pemasaran produk pada industri tempe Sucipto dapat dilihat pada tabel dibawah ini :

\begin{tabular}{|c|c|c|}
\hline Tempat penjualan & Mekanisme & $\begin{array}{l}\text { Perjanjian } \\
\text { pembayaran hasil } \\
\text { penjualan }\end{array}$ \\
\hline \multicolumn{3}{|l|}{ Supermarket: } \\
\hline Freshmart & Diantar langsung oleh industri & Konsinyasi \\
\hline Golden & Diantar langsung oleh industri & Konsinyasi \\
\hline Hypermart & Diantar langsung oleh industri & Konsinyasi \\
\hline Jumbo & Diantar langsung oleh industri & Konsinyasi \\
\hline Multimart & Diantar langsung oleh industri & Konsinyasi \\
\hline Indogrosir & Diantar langsung oleh industri & Konsinyasi \\
\hline
\end{tabular}

Tabel 3 menunjukan bahwa cakupan pemasaran produk tempe Sucipto walaupun masi dikategorikan industri rumah tangga, produk yang dihasilkan sudah mampu bersaing dipasar moderen. Perjanjian pembayaran hasil penjualan melalui sistem konsinyasi yaitu pembayaran melalui nota.

\section{Modal}

Modal menurut (Soekartawi 2003) modal dapat dibedakan menjadi 2 macam yaitu modal tetap dan modal tidak tetap. Modal tetap dapat didefinisikan sebagai biaya yang dikeluarkan dalam proses produksi yang tidak habis dalam satu kali proses produksi. Contoh modal tetap adalah tanah, bangunan, mesin, dan lain-lain. Sedangkan modal tidak tetap adalah biaya yang dikeluarkan dalam proses produksi berulang-ulang, misalnya bahan baku, bahan bakar dan lain-lain.

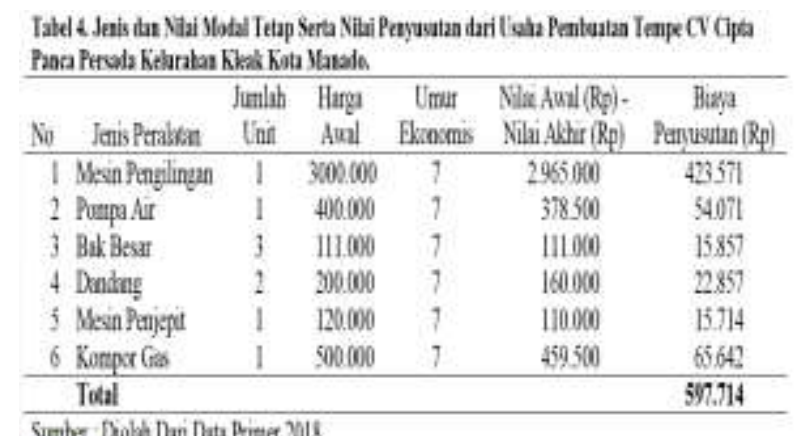

Tabel 4 dapat dilihat modal tetap sebanyak Rp.4.157.000. selain itu dapat dilihat nilai penyusutan alat sebesar Rp.597.714. Sedangkan jenis dan nilai modal tidak tetap dalam usaha industri tempe dapat dilihat pada tabel 5 dibawah ini. 
Tabel 5. Modal Tidak Tetap Selama Satu Kali Proses produksi pada industri tempe "Sucipto" Kecamatan Kleak Kota Manado.

\begin{tabular}{clc}
\hline No & Jenis Alat Dan Bahan & Jumlah $(\mathrm{Rp})$ \\
\hline 1 & Bahan Baku Kedelai & 410.000. \\
2 & Ragi Tempe & 18.000. \\
3 & Daun Pisang & 10.000. \\
4 & Kemasan Pelastik & 10.000. \\
5 & Bahan Bakar Gas & 30.000. \\
6 & Bahan Bakar Kendaraan & 300.000. \\
\hline & Total & $\mathbf{7 7 8 . 0 0 0 .}$ \\
\hline
\end{tabular}

Sumber : Diolah Dari Data Primer 2018.

Tabel 5 diatas dapat dilihat jenis modal tidak tetap sebanyak Rp.778.000 dalam satu kali proses produksi. Sedangkan selama satu bulan proses produksinya biaya yang dikeluarkan oleh CV Cipta Panca Persada adalah sebesar Rp.23.340.000.

\section{Analisis Total Biaya, Penerimaan dan Keuntungan}

Dalam kegiatan produksi dapat dinilai hasil yang diperoleh dari biaya yang dikeluarkan selama produksi berlangsung. Adapun data yang dianalisis adalah biaya produksi yang terjadi dalam satu kali produksi selama bulan September 2018.

\section{a. Biaya Tetap}

Biaya tetap adalah biaya yang tidak tergantung banyak sedikitnya produk yang dihasilkan. Dalam usaha pembuatan tempe CV Cipta Panca Persada yang termaksud dalam biaya tetap adalah biaya penyusutan alat.

Tabel 6. Jenis Alat Dan Jumlah Biaya Tetap Dari Penyusutan Alat Selama Bulan Juli 2018.

\begin{tabular}{clcc}
\hline No & Jenis Alat & $\begin{array}{c}\text { Lama Pemakaian } \\
\text { Tahun }\end{array}$ & $\begin{array}{c}\text { Nilai Penyusutan } \\
\text { (Rp) }\end{array}$ \\
\hline 1 & Mesin & 7 & 423.571 \\
2 & Penggiling & 7 & 54.071 \\
3 & Bompa Air & 7 & 15.857 \\
4 & Dandang & 7 & 22.857 \\
5 & Mesin Penjepit & 7 & 15.714 \\
6 & Kompor Gas & 7 & 65.642 \\
\hline & Total & & $\mathbf{5 9 7 . 7 1 4}$
\end{tabular}

Sumber diolah dari data primer, 2018

Dari Tabel 6 diatas dapat dilihat bahwa biaya penyusutan alat yang merupakan biaya tetap sebesar Rp. 597.714 dengan lama pemakaian alat 7 tahun. Nilai penyusutan yang paling besar dari alat mesin pengiling, sedangkan nilai penyusutan alat paling kecil dari alat mesin penjepit.

\section{b. Biaya Variabel}

Biaya variabel adalah biaya yang dikeluarkan untuk faktor produksi yang memiliki sifat berubah-ubah dan akan mempengaruhi besarnya volume produksi atau yang direncanakan. Biaya variabel dalam penelitian ini adalah biaya bahan baku, biaya pengemasan, biaya bahan bakar, dan biaya tenaga kerja yang dihitung selama bulan September 2018.

Pada Tabel 7 dapat dilihat perincian biaya variabel (variable cost) yaitu pengeluaran yang tidak tetap pada usaha pembuatan tempe CV Cipta Panca Persada selama bulan Juli 2018.

Tabel 7. Biaya Variabel Usaha Pembuatan Tempe CV Cipta Panca Persada Pada Bulan Juli 2018.

\begin{tabular}{clr}
\hline No & Biaya Variabel & Jumlah (Rp) \\
\hline 1 & Bahan Baku & 12.300 .000$. \\
2 & Bahan Penolong & 18.000. \\
3 & Bahan Bakar Gas & 360.000. \\
4 & Tenaga Kerja & 1.900 .000$. \\
5 & Bahan Bakar Kendaraan & 600.000. \\
6 & Pengemasan & 600.000. \\
\hline & Total & $\mathbf{1 5 . 7 7 8 . 0 0 0 .}$
\end{tabular}

Sumber diolah dari data primer, 2018.

\section{Total Biaya}

Perhitungan total biaya produksi usaha pembuatan tempe CV Cipta Panca Persada merupakan penjumlahan biaya tetap dengan biaya variabel yang meliputi biaya bahan baku, bahan penolong, bahan bakar gas, tenaga kerja, bahan bakar kendaraan, dan biaya pengemasan. Pada usaha ini mempunyai biaya tetap meliputi biaya penyusutan peralatan sebesar Rp. 597.714. sedangkan biaya variabel sebesar Rp.15.778.000. Sehingga total biaya yang dikeluarkan untuk proses produksi selama Septem-ber 2015 yaitu sebesar Rp.16.775.714. Untuk lebih jelas dapat dilihat pada Tabel 8 dibawah ini.

Tabel 8. Total Biaya Usaha Pembuatan Tempe CV Cipta Panca Persada Selama Bulan Juli 2018

\begin{tabular}{|c|c|c|}
\hline No & Uraian Biaya & Nilai Rp \\
\hline \multirow[t]{4}{*}{1} & Biaya Tetap & \\
\hline & Biaya Penyusutan Alat & 597.714 \\
\hline & Biaya Listrik & 400.000 \\
\hline & Jumlah Biaya Tetap & 997.714 \\
\hline \multirow[t]{9}{*}{2} & Biaya Variabel & \\
\hline & Bahan Baku & 12.300 .000 \\
\hline & Bahan Penolong & 18.000 \\
\hline & Bahan Bakar Gas & 360.000 \\
\hline & Tenaga Kerja & 1.900 .000 \\
\hline & Bahan Bakar Kendaraan & 600.000 \\
\hline & Pengemasan & 600.000 \\
\hline & Jumlah Biaya Variabel & 15.778.000 \\
\hline & Total Biaya & $\mathbf{1 6 . 7 7 5 . 7 1 4}$ \\
\hline \multicolumn{3}{|c|}{ Sumber diolah dari data primer, 2018.} \\
\hline \multicolumn{3}{|c|}{$\begin{array}{l}\text { Perhitungan total biaya produksi CV Cipta Panca Persa } \\
\begin{aligned} \text { Total Biaya } & =\text { Total Biaya Tetap + Total Biaya Variabel } \\
& =\text { Rp. } 997.714+\text { Rp. } 15.778 .000 \\
& =\text { Rp. } 16.775 .714\end{aligned}\end{array}$} \\
\hline
\end{tabular}

\section{Penerimaan}

Penerimaan merupakan suatu hasil yang diterima oleh perusahaan setelah menujual produksinya kepada konsumen akhir. Penerimaan adalah hasil yang diperoleh dari jumlah produksi dikali dengan harga jual. Berikut ini tabel penerimaan dari CV Cipta Panca Persada. 


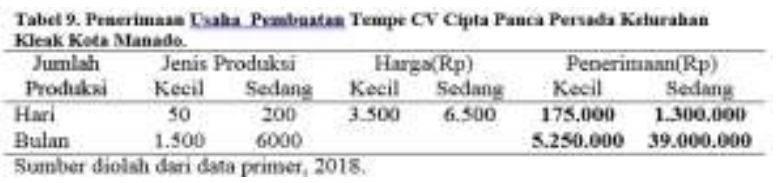

Tabel 9 menunjukkan diatas dapat dilihat penerimaan pada industri tempe Sucipto dalam satu kali produksi sebesar Rp.1.475.000, dan dalam satu bulan produksi sebesar Rp.39.000.000.

\section{Keuntungan}

Besar keuntungan yang diterima oleh industri tergantung pada penerimaan dan pengeluaran yang ada dalam industri itu sendiri. Penerimaan sangat tergantung pada harga jual produk yang telah ditetapkan oleh industri, sedangkan pengeluaran yang terjadi dalam industri berhubungan dengan biaya produksi. Penerimaan dapat diperoleh darihasil perkalian antara harga jual produk dengan jumlah produksi. Dengan mengetahui penerimaan dengan pengeluaran, maka keuntungan dapat dihitung berdasarkan pengurangan antara jumlah penerimaan dan jumlah pengeluaran. Berikut perhitungan keuntungan usaha :

Keuntungan $=$ Total Penerimaan - Total Biaya

$$
\begin{aligned}
& =\text { Rp .39.000.000. - Rp.16.775.714. } \\
& =\text { Rp. 22.224.286. }
\end{aligned}
$$

Dari hasil yang didapat bahwa total keuntungan yang diperoleh CV Cipta Panca Persada pada ukuran kecil dan sedang Rp. 22.224.286 dengn total biaya produksi sebesar Rp.16.775.714. Dimana produk ini dijual dengan harga Rp.3.500,- untuk ukuran kecil dan Rp.6.500,- untuk ukuran sedang.

\section{KESIMPULAN DAN SARAN}

\section{Kesimpulan}

CV Cipta Panca Persada merupakan usaha berskala kecil yang menggunakan bahan baku kedelai untuk diolah menjadi tempe. Kegiatan proses produksi pemilik usaha dibantu oleh 2 tenaga kerja dari dalam keluarga dan 1 orang tenaga kerja yang berasal dari luar Manado. Pemasaran dilakukan oleh pemilik usaha yang berhadapan langsung dengan konsumen (Supermarket) untuk menjual produk Tempe yang dihasilkan. Dari hasil penelitian yang dilakukan usaha pembuatan tempe CV Cipta Panca Persada mengalami keuntungan sebesar Rp. 22.224.286.

\section{Saran}

Berdasarkan hasil penelitian, maka saran yang dapat diberikan dalam kemajuan CV Cipta Panca Persada yaitu diharapkan tetap mempertahankan keuntungan yang diperoleh dengan cara lebih memperhatikan persediaan bahan baku agar mendapatkan hasil yang optimal dan dapat meningkatkan produksi.

\section{DAFTAR PUSTAKA}

Anonimous, 2011. Company Profile. http://ayuprint.co.id/company-profile/

Diakses tanggal 10 april 2018 Pukul 10:58 Wita

Anoraga, P. \& J. Sudantoko. 2002. "Koperasi Kewirausahaan dan Usaha Kecil. Rineka Cipta". Jakarta.

Ariadi Yudi Bambang dkk. 2011. Sistem Agribisnis Terintegrasi Hulu-Hilir. Muara Indah, Bandung

Aulani Kusaeri 2014. Analisis Pendapatan Dan Fungsi Produksi Tempe Pada Industri Pola Kemitraan Dan Pola Mandiri. (Kasus Desa Cimanggu I Kec. Cibungbulang Kab. Bogor). Skripsi.

Cahyadi, W. 2006. Kedelai Khasiat dan Teknologi. Bandung. Bumi Aksara.

Kasryno et. Al. 1985. Pemasaran Kedelai di Indonesi di dalam Soemaatmaja $S$ et.al., (Ed). Kedelai. Bogor Badan penelitian dan Pengembangan Pertanian pusat Penelitian dan pengembangan Tanaman Pangan.

Koagouw. P Putra 2014. Profil Usaha Agroindustri "Kue Bepang" Di Kecamatan Remboken. Skripsi.

Khazanani, A., SBM, N., \& Nugroho, S. B. M. Nugroho. "Analisis Efisiensi Penggunaan FaktorFaktor Produksi Usahatani Cabai Kabupaten Temanggung” (Studi Kasus di Desa Gondosuli Kecamatan Bulu Kabupaten Temanggung). Diss. Universitas Diponegoro, 2011.

Ryanto, B. 2010. "Analisis Laporan Keuangan”. Liberty. Yogyakarta.

Santoso, W., Utami, P. dan Dumasari. 2009. “Analisis Pendapatan dan Biaya Produksi Agroindustri Tahu di Desa Pandansari kecamatan Ajibarang Kabupaten Banyumas". Jurnal. Fakultas Pertanian. Universitas Muhammadiayah Purworkerto.

Simamora, 2000. "Akutansi". Basis Pengembalian Keputusan Bisnis. Jild Satu. Salemba Empat. Jakarta.

Soekartawi. 2001. "Pengantar Agroindustri". Jakarta. 2002. "Teori Ekonomi Pertanian". PT. Raja Grafindo Persada. Jakarta. 2006. "Analisis Usaha Tani. UI Press. Jakarta.

Sukirno, S. 2002. "Pengantar Teori Makro Ekonomi”. PT. Raja Grafndo. Jakarta.

Supriyono, R.A, 2000. “Akutansi Biaya". Perencanaan dan Pengendalian Biaya serta pembuatan keputusan, Edisi kedua, BPFE, Yogyakarta. 